\title{
Lingual Investigation of President Soekarno Speech: A Report
}

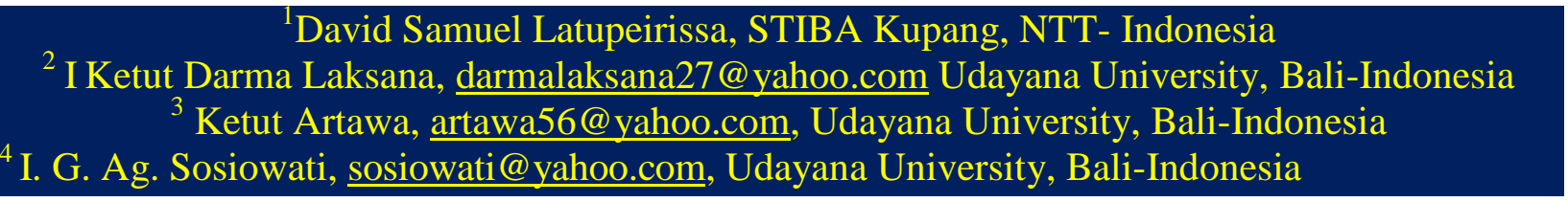

*Corresponding Author: latupeirissadavid1@gmail.com

Received Date: 10-01-2019 Accepted Date: 28-02-2019

Published Date: 31-07-2019

\begin{abstract}
The current research aims at investigating the most important speech of Soekarno and the ideologies behind the speech. Since Soekarno was the proclaimer of Indonesian independence as well as the first president of Indonesia, we would claim that his speeches were important to be investigated. Among the speeches, we tried to reveal the most important one through a lingual investigation. This investigation was based on grounded theory and hermeneutic theory. It was focused on the text as a part of the language. The results have shown that the most important speech of Soekarno is the speech entitled, 'Tahun Berdikari'. It is viewed as a high novelty finding because there is no researcher who has ever claimed 'Tahun Berdikari' as the most important speech in the history of Indonesia. The speech contained three main ideologies, namely (1) unity as the most important thing for Indonesians, (2) revolution must be in the Indonesian soul, and (3) imperialism and capitalism as Indonesia's main enemy.
\end{abstract}

Keywords: Soekarno's Speech, Discourse, Grounded Theory, Hermeneutics

\section{Introduction}

Political speech is a genre of political discourse and is part of public discourse. It is characterized by formal lexis and monolog form and it is usually carefully crafted by professional speechwriters, which leaves no room for improvisations on the part of the speaker (Matić, 2012). The study of political discourse itself, that focus on political speech, has become a very crucial study especially in the area of the ideology behind a political language.

In line with the above statement, Thomans \& Wareing (1999) states that political speech, through indirect manipulation of language, impulses people to do or not to do something. Skillful speakers of the political language are able to influence the preconceptions, views, ambitions, and fears of the public (Norman, 1989; David, 2014). They can persuade people to accept false

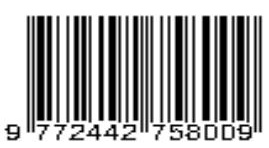


statements as true postulates, or even support policies conflicting with their interests. Preconception, views, postulates, belief, etc, are parts of ideology that contain in political language (cf. McLellan, 1986; Erikson \& Tedin, 2003). Counting such ideas, it is stated that any political speech is important to be investigated, especially in the area of its ideology.

This paper was written to investigate the most important speech of Soekarno. Soekarno was the proclaimer of Indonesian independence, as well as the first president of Indonesia. His speeches, theoretically, are believed as the basics formation of Indonesian social construction (cf. Fairclough, 2006). We believe that the result of the current investigation will contribute to the field of Political Discourse, Critical Discourse Analysis, as well as The History of Indonesia. The finding of the most important speech, especially the one which is related to ideology that constructed social phenomena of Indonesia, will direct any future researchers of Political Discourse, or Critical Discourse Analysis, and Historians, etc., to explore the speech for humanity and scientific purposes.

\section{Research Methods}

We applied qualitative research that was based on Grounded Theory and Hermeneutics. The Grounded Theory is a logically consistent set of data collection and analytic procedures aimed to develop a theory (Charmaz, 2014). It is a kind of inductive strategy for analyzing data. A major contribution of the grounded theory method is that it provides rigorous procedures for researchers to check, refine and develop their ideas and intuitions about the data (Bryant et al, 2007). Charmaz (2014), furthermore, stated that the term grounded theory denotes dual referents; (a) a method consisting of flexible methodological strategies and (b) the products of this type of inquiry.

In the current research, rigorous procedures were set to investigate Soekarno's speeches. The methodology was rather flexible. Firstly, we went to the Indonesian Republic National Archives (IRNA) in South Jakarta- Indonesia, and National Library of Indonesia Republic in Central Jakarta- Indonesia. Secondly, we investigated the archive of Soekarno's Speech by reading and comparing them. Thirdly, we decided the smaller corpora. The last, from the corpora we applied hermeneutics principles to decide the most important speech. The research was conducted for two years, that is, from 2016 to 2018.

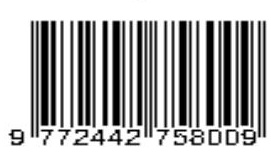




\section{Result and Discussion}

Our research, as has been stated above, was firstly conducted by visiting Indonesian Republic National Archives (IRNA) and National Library of Indonesia Republic. IRNA was located in Ampera Raya Street No. 7 South Jakarta, while the National Library of Indonesia Republic was located in the 27 Salemba street, Central Jakarta. Both of them were the places where original state documents were kept. IRNA was the office storage of Soekarno's speeches that retrieved directly from the office of the Indonesia State Secretariat while The National Library of Indonesia saved the original documents of Soekarno's speech that have already published. The places mentioned above were chosen for the sake of getting genuine documents.

In IRNA, there were 919 documents of Soekarno speeches and memos/ notes of Soekarno. After reading all the documents, we have found that Soekarno put more attention on speeches that delivered on August $17^{\text {th }}$ s. Soekarno himself stated that particular August $17^{\text {th }}$ speeches were important (Siswo, 2014). The statement is displayed in the following data.

Data 1. Tahun jang lalu, saja menamakan hari ulang tahun Proklamasi satu hari jang unik. Satu hari jang istimewa, satu hari jang menondjol, satu hari jang luar biasa...

In the last year, I called Proclamation Anniversary day as a unique day, a special day, a prominent day, an extra ordinary day....

Data 2. Sebetulnja tiap hari 17 Agustus adalah hari istimewa...

Every August $17^{\text {th }} \mathrm{s}$ is an exceptional day...

Data 1 and 2 above were taken from Soekarno's speech entitled "Laksana Malaikat yang Menyerbu dari Langit", that was delivered in August, $17^{\text {th }} 1960$. The data are examples of many others which show that Soekarno, himself, very admired the days of August $17^{\text {th }}$ s. Another example was taken from the speech entitled “Jangan Sekali- Sekali Melupakan Sejarah”. The speech was delivered on August $17^{\text {th, }}$ 1966. One of Soekarno's statement is shown in the data 3.

Data 3. Memang pada tiap- tiap 17 Agustus seluruh dunia dan seluruh umat manusia mengarahkan perhatiannya kepada Djakarta, karena mereka ingin mengetahui...

In every August $17^{\text {th }} \mathrm{s}$, indeed, the world, as well as all human beings, give their attention to Djakarta (the capital city of Indonesia), because they want to know...

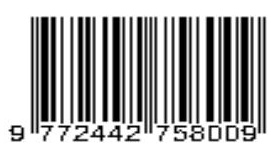


It is known from data 3 that Soekarno had the perception that all the people in the world focused and gave their special attention to Indonesia. Based on this perception, we would say that Soekarno prepared his best in delivering August $17^{\text {th }}$ s' speeches.

Having known the phenomena, we focused on the speeches that delivered by Soekarno in August $17^{\text {th }} \mathrm{s}$. There were 21 speeches of Soekarno that categorized as important speeches. The speeches were delivered on August $17^{\text {th }}$, started from the year 1945 to the year 1966. On this stage, we examined all the speeches by applying the technique of "critical discourse reading". As a result of applying the technique, we have had a speech that categorized as the most important speech of Soekarno.

Taking those thoughts into account, this research has found that the most important speech of Soekarno's Political Speech (SPS), based in our lingual investigation, is the speech under the title of 'Tahun Berdikari'. It was delivered by Soekarno on August $17^{\text {th, }} 1965$. Following is the explanation of our research's result of applying "critical discourse reading" (see. Fairclough, 1995).

The SPS 'Tahun Berdikari' was selected for several reasons. The first reason, Soekarno himself, as has been stated previously, stated that the speeches of August $17^{\text {th }}$ were very important (Siswo, 2014). Among the speeches, 'Tahun Berdikari' was the most important speech since it was the only speech that contains a summary of all the August speeches, that Soekarno delivered from August, $17^{\text {th }} 1945$ - August, $17^{\text {th }}$ 1959. In other words, it incorporates the complete ideology of SPL. The following diagram describes how this speech contained the complete ideology of Soekarno.

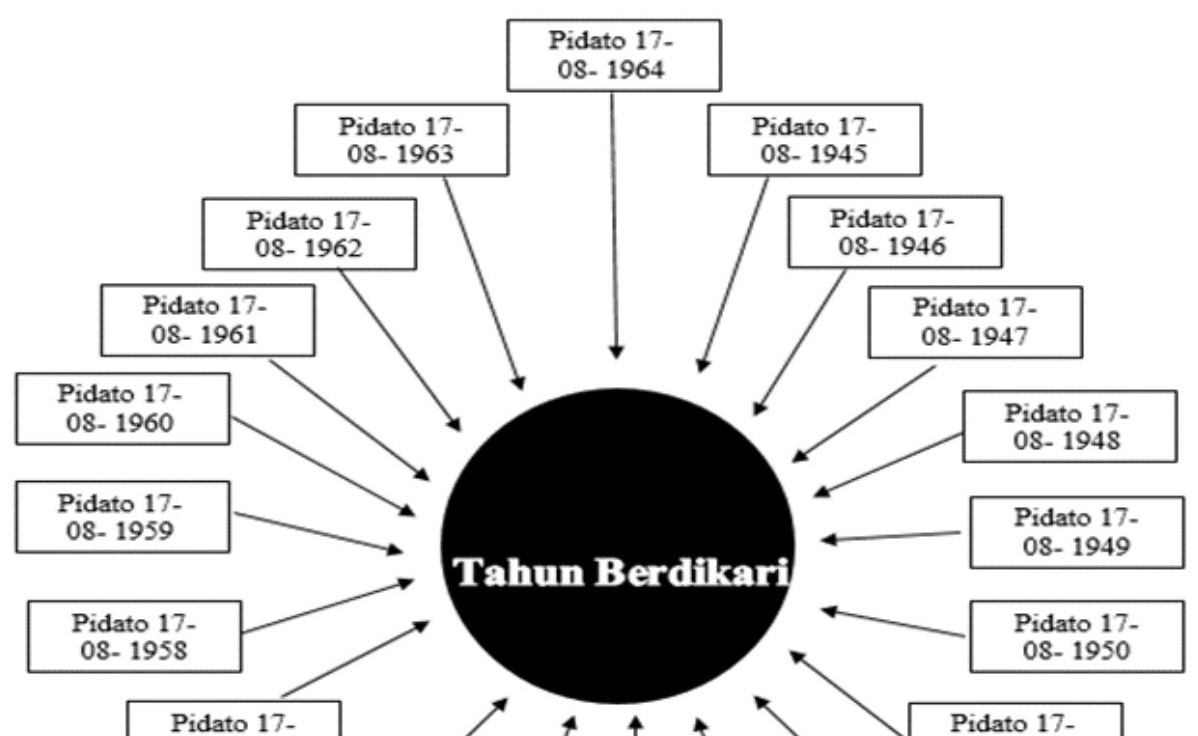




\section{Diagram 1}

The existence of "Tahun Berdikari" Speech"

Note:

= The speech which contains the most ideology concepts of Soekarno

$\longrightarrow=$ The main ideology of a speech was restated in "Tahun Berdikari" speech.

Pidato $=$ Speech

The second reason is described as follows. In 1965, Indonesia faced critical times as the communist party maneuvered to kill a number of Indonesian generals. This was followed by the tragedy of large-scale killings and civil unrest which occurred over several months, targeting communist sympathizers, ethnic Chinese and alleged leftists, often at the instigation of the armed forces and government (Melvin, 2017). Hermeneutically, as the president, with evidence of foresight, Soekarno appeared to feel and sense the crisis before the tragedy happened. For sure, he constructed and delivered his best political speech in that year. That is why the speech of 'Tahun Berdikari' was selected to be the most important speech.

On the further investigation of the speech, we have found some important clues that will lead them to the revelation of ideology. First, there were 145 segments in SPS. Second, on the segments, there were more than 14 main ideas/ issues discussed by Soekarno. The topics were 1) unity, 2) revolution, 3) imperialism/ capitalism, 4) history of the Indonesian nation, 5) thanksgiving for many positive aspects that have been given to Indonesian people, 6) the spirit of struggling in gaining freedom, 7) the meaning of freedom, 8) do not give up in facing difficulties, 9) nationalism, 10) the spirit of independence, 11) real leadership, 12) culture, 13)

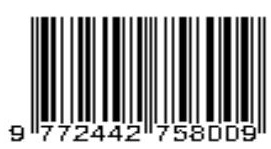


spiritual braveness, and 14) the ideology of marhaenism. Third, the dominant issues were unity, revolution, and imperialism.

Soekarno discussed 'unity for Indonesian'. The theme of unity dominates $30 \%$ of the whole text. Semantically, there are 119 lexicons that related to the topic of unity as the most important thing for Indonesians. The lexicons were used to persuade people to be united. On the analysis of context, it would be explained the whyness of this persuasion.

The second dominant topic that has been identified, was about revolution. The researchers have found that Soekarno constructed 39 segments speaking to speak about revolution. It features in $27 \%$ of the whole text. The general meaning of these segments is that 'revolution itself that must be sustained and continually lived out by all Indonesian people'. Both the first and second topics are repeatedly expressed in SPS. Overall, there are 204 lexicons that are semantically related to the topic of revolution. There are 164 lexicons of the word 'revolution', and 40 lexicons of the word 'revolutionary'.

The third dominant topic that has been identified, was imperialism and capitalism. The total construction of segments that speak about it was 31 . It features in $22 \%$ of the text as a whole. Semantically, there are 76 lexicons that relate to this third topic. Using the lexicons, Soekarno constructed the ideology into Indonesian people. Following is the chart of SPS' topics/ issues. 

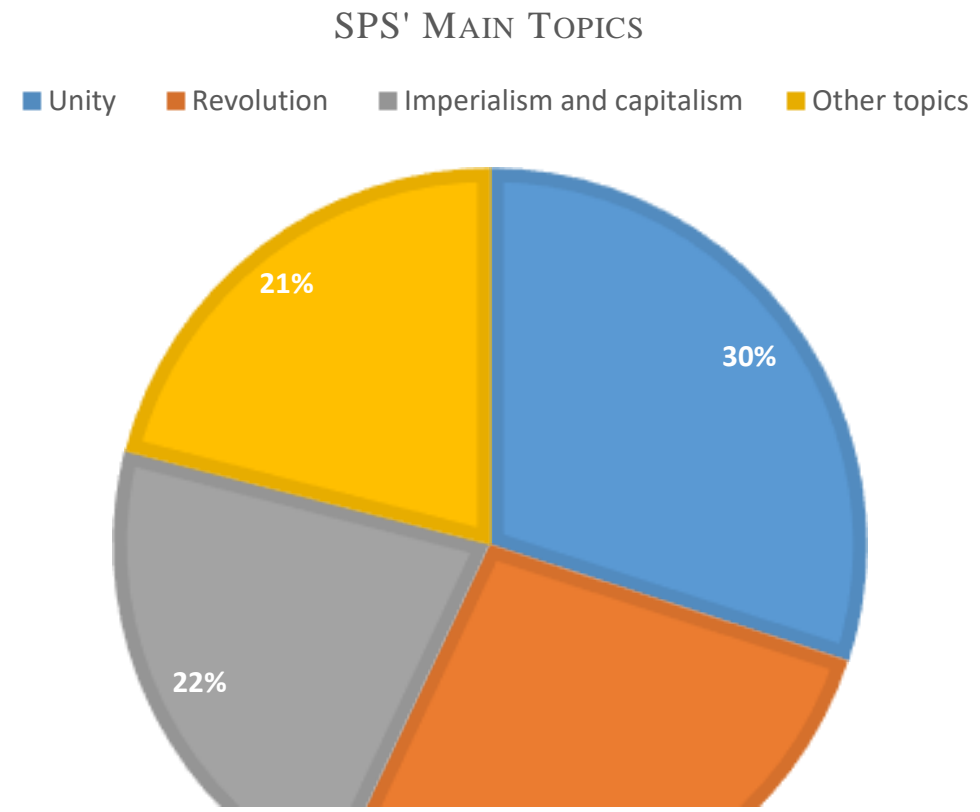

Figure 1

The Dominant Issues of SPS

Other topics, collectively comprising 21\%, talk about: (1) history of the Indonesian nation, (2) thanksgiving for many positive aspects that have been given to Indonesian people, (3) the spirit of struggling in gaining freedom, (4) the meaning of freedom, (5) do not give up in facing difficulties, (6) nationalism, (7) the spirit of independence, (8) real leadership, (9) culture, (10) spiritual braveness, and (11) the ideology of marhaenism. The eleven ideas above, overall, are only $1.9 \%$ of the SPL. In other words, they are not dominant in the text. The dominant ideas, or the main topics, are 'unity', 'revolution soul', and 'Imperialism and Capitalism'. Having conducted the analysis, the researchers believe that the findings of the main topics or dominant issues of SPS have led them closer to the revelation of the ideology behind SPS.

\section{Novelties}

Having done the analysis, there are some novelties of this study which are presented as follows. First, in the history of Indonesia, there is no one who has ever stated that the most important SPS is 'Tahun Berdikari'. Based on our examination, we have found that 'Tahun Berdikari' is the most important SPS. Second, there is a belief among Indonesian People that Marhaenism and Nasakom were the main ideology of Soekarno (Wibowo, 2005; Kuswono, 2016; Winata, 2017). Based on the current research's finding, we have found that the belief was

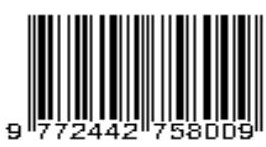


not correct. The Marhaenism and Nasakom were only 'branch' of three main ideologies, that is, 'unity as the most important thing for Indonesians', 'revolution must be in the Indonesian soul', and 'Imperialism and Capitalism as Indonesia's main enemy'.

\section{Conclusion}

Based on our investigation, we concluded that the important speeches of Soekarno were the speeches of August $17^{\text {th }}$ s. Among them, the "Tahun Berdikari" speech is the most important one. Related to the finding, we conducted a further investigation about the ideologies of the speech. We have found that the three main ideologies of the speech were 'unity as the most important thing for Indonesians', 'revolution must be in the Indonesian soul', and 'Imperialism and Capitalism as Indonesia's main enemy'.

\section{References}

Bryant, Antony, and Charmaz, Kathy. (2007). 'Grounded theory in historical perspective: An epistemological account', in Bryant, A., and Charmaz, K. (eds.), The SAGE Handbook of Grounded Theory. Los Angeles: Sage. pp. 31-57.

Charmaz, K. (2014). Constructing grounded theory. Sage.

David, M. K. (2014). Language, power, and manipulation: the use of rhetoric in maintaining political influence. Frontiers of Language and Teaching, 5(1), 164-170.

Erikson R.S, Tedin K.L. (2003). American Public Opinion. New York: Longman. 6th ed.

Fairclough, N. (2006). Discourse and Social Change. Cambridge: Polity Press.

Kuswono, K. (2016). Marhaenism: Social Ideology Create by Sukarno. HISTORIA Jurnal Program Studi Pendidikan Sejarah, 4(2), 119-130.

Matić, D. (2012). Ideological discourse structures in political speeches. Komunikacija i kultura online, 3(3), 54.

McLellan D. (1986). Ideology. Minneapolis: Univ. Minn. Press

Norman, F. (1989). Language and power. London and New York: Longman.

Siswo, I. (2014). Panca Azimat Revolusi: Tulisan, Risalah, Pembelaan, \& Pidato Sukarno 19261966. Jakarta: KPG

Thomans, L., \& Wareing, S. (1999). Language, Society, and Power. London: Routledge

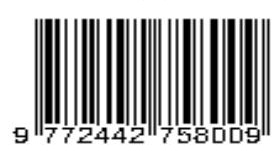


Fairclough, N. (1995). Critical Discourse Analysis: The Critical Study of Language. London: Longman

Melvin, J. (2017). "Mechanics of Mass Murder: A Case for Understanding the Indonesian Killings as Genocide". Journal of Genocide Research. 19 (4): 487-511. https://doi:10.1080/14623528.2017.1393942.

Wibowo, Y. S. (2005). Marhaenisme: ideologi perjuangan Soekarno. Buana Pustaka.

Winata, L. (2017). Nasakom Sebagai Ideologi Negara Tahun 1959-1965. Avatara, 5(3).

\section{Acknowledgments}

I would like to express my deep appreciation and thanks to those who have given me hight motivation to finish this work; my nuclear family, parents, and sisters. 